\title{
Az arc-állcsont régióban végzett csontpótló mútétek összehasonlító Cone Beam Computed Tomography (СBCT) vizsgálatára alkalmas mérési módszer definiálása és standardizálása
}

\author{
DECKER ROLAND*, DR. FÁBIÁN ZOLTÁN*, DR. DECKER IVÁN**, DR. BOGDÁN SÁNDOR* ${ }^{\star *}$, \\ DR. RESTÁR LÁSZLÓ***, DR. DÚCZ ANDRÁS****, DR. NÉMETH ZSOLT*, DR. HUSZÁR TAMÁS**
}

\begin{abstract}
Az arc-állcsont régióban végzett csontpótló mútétek eredményességének objektív összehasonlító vizsgálata nem megoldott. Ennek oka, hogy a fogászatban, szájsebészetben alkalmazott képalkotó eljárásokkal különböző időpontokban készített felvételek objektív összehasonlítása nehézségekbe ütközik. Léteznek software-ek, melyek alkalmasak összehasonlító vizsgálatokra, de alkalmazásuk nehézkes, az eredmények nem megbízhatók. Az arc-állcsont régióban alkalmazható, standardizált összehasonlító eljárás még nincs kidolgozva.

Célkitüzés: 1) Csontpótló mútétek összehasonlító CBCT (Cone Beam Computed Tomography) analízisére alkalmas módszer létrehozása és ellenőrzése. 2) Módszertani ajánlás készítése.

Anyag és módszer: 6 páciens két különböző időpontban készült CBCT felvételeinek összehasonlítása történt $H_{0 r o s}{ }^{T M}$ orvosi képfeldolgozó programmal, illesztési hiba meghatározása alapján. A vizsgálatot 4 független személy végezte. Vizsgálati csoportok: 1) Standard anatómiai pontok alapján végzett mérések, 2) Egyedi radiológiai pontok alapján végzett mérések.

Statisztika: minden vizsgáló által 3 mérés/eset. Értékelés: Mann-Whitney U teszt (SD /Standard Deviaton/ $p \leq 0,05$ ).

Eredmények: Az illesztési hiba mértéke minden vizsgáló esetében szignifikánsan alacsonyabb volt az egyedi pontok által mért esetekben, az anatómiai pontok alapján mért értékekhez képest (vizsgáló 1: 0,463 $\pm 0,103$ vs. 0,283 $\pm 0,030$; vizsgáló 2: $0,499 \pm 0,100$ vs. 0,318 $\pm 0,040$; vizsgáló 3: 0,647 $\pm 0,555$ vs. 0,291 $\pm 0,388$; vizsgáló 4: 0,607 $\pm 0,069$ vs. $0,281 \pm 0,033)$.

Következtetések: A Horos ${ }^{T M}$ képfeldolgozó programmal végzett illesztési hiba mérési módszerrel lehetséges objektív összehasonlító vizsgálatot végezni ugyanazon személy két eltérő időpontban készült CBCT felvételén. Legpontosabb méréseket, a lehető legnagyobb háromszöget körülhatároló, három, egyedi radiológiai mintázatot jelölő pont kijelölésével lehet elérni.
\end{abstract}

Kulcsszavak: $\mathrm{CBCT}$, összehasonlító CBCT analízis, csontpótlás, arc-állcsont régió, Horos ${ }^{T M}$

\section{Bevezetés}

Az arc-állcsont régióban kialakult csonthiányok, atrófiás állcsontgerinc csontpótlására nagyon sok eljárást dolgoztak ki. A különböző módszerek hatékonyságának, sikerességének felmérésére alkalmas objektív vizsgáló módszert még nem sikerült kifejleszteni, ez megnehezíti az egyes csontpótló mútétek tudományosan alátámasztott módszertani értékelését [5, 15, 22].

A csontpótló beavatkozások sikerességének megállapítása három alapvető módszertani vizsgálaton alapul: 1) klinikai méréseken: szondázás, inspekció csontméretmérés tolómércével (caliper), 2) szövettani, hisztomorfometriai vagy 3) valamilyen képalkotó eljárással (OP, CBCT, CT, standardizált fogászati rtg felvétel) végzett méréseken. A klinikai vizsgálatok a csontminő- ségre, a nem csontos kötőszöveti elemek arányára és minőségére, valamint a gyulladásos tünetek leírására szorítkoznak. A szövettani vizsgálatokkal a képződött új csont minőségét, kötőszöveti elemekhez, csontpótló anyag jelenlétéhez mért arányát lehet meghatározni [17, 18]. A képalkotó eljárásokkal a csont térfogata, magassága, szélessége változásának illetve denzitásának mértékét lehet értékelni $[3,5,10,11,16,21,23]$.

A digitális felvételeken a mérések általában valamilyen képnézegető program segítségével történnek, ami a klinikai értékeléshez általában elegendő, de tudományos igényü, objektív összehasonlító vizsgálatokra nem alkalmasak, még a beépített lineáris méréseket lehetővé tévő eszközök segítségével sem [10, 18].

Az alkalmazott képalkotó eljárások közül a leggya- 
koribb az ortopántomográfia (OP), amely kiváló képet ad a rágókészülék kemény szöveteinek állapotáról. Ez a tomográfiai eljárás a röntgencső és a detektor a fogívek görbületének megfelelő forgása és transzlációja következtében jön létre, amely során a fogíveken belüli és kívüli képletek árnyéka expozíció közben csúszik a detektoron, a fogívek görbéjével párhuzamos síkban lévő képletek árnyéka statikusan vetül a detektorra, ezért azon értelmezhető kép keletkezik. Annak ellenére, hogy vertikális síkban használható akár mérésekre is, szagittálisan jelentősen torzít, transzverzálisan nem nyújt semmiféle információt [12].

Az implantológia, illetve az állcsontgerincek rekonstrukciója a pontosabb tervezés céljából egyre inkább szükségessé tette az állcsontokról háromdimenziós képek alkotását. A multislice CT-k nagyobb sugárterhelése, nehéz hozzáférhetősége nem volt járható út. A megoldást a digitális volumen-tomográfia hozta el.

A CBCT sugárterhelése 2-8 panorámafelvétel sugárterhelésének felel meg, szemben a hagyományos multislice CT dózisával, ami 200-300 panorámafelvétellel egyenlő.

A CBCT-készülékek esetén alkalmazott kisebb intenzitású sugárzás miatt a felvételeken mérhető denzitásértékek nem olyan pontosak, mint a hagyományos CT-n mért értékek [13].

A csontméret változásainak tudományos értékủ mérésére a CBCT-felvételek alkalmasak, mivel - ha pontosan ki lehet jelölni a mérendő területet - századmilliméter pontossággal mérhetők a hosszúsági paraméterek.

A CBCT bevezetése forradalmasította az arc-állcsont régióban végzett csontmútétek diagnosztikáját, tervezését, a műtétek kivitelezését. Erre legjobb példa a navigációs implantológia, a rekonstrukciós implantátumok tervezése, gyártása CAD/CAM (Computer-Aided Design/Computer-Aided Manufacturing) módszerrel, digitális modellmútétek ortognath mútétek tervezéséhez [4].

A CBCT-felvételeken végzett mérések pontossága kielégíti mind a klinikai vizsgálatok, mind a hétköznapi gyakorlat igényeit, azonban sorozatfelvételek egymással való objektív összehasonlítása nem megoldott, hiszen a mérési pontok szinkronizált kihelyezésére nem volt lehetőség.

Idegsebészetben és onkológiában elterjedtek a képfúziós eljárások, pl. PET/CT (Positron Emission Tomography/Computed Tomography), MRI/CT (Magnetic Resonance Imaging/Computer Tomography) [9]. A szájsebészetben az igény ezekre az összehasonlító mérésekre az egyedi implantátumok-, csontgraftok-, navigációs mútétek tervezése és kivitelezése kapcsán [7, 8], illetve a csontpótló beavatkozások eredményességének objektív vizsgálata iránti igény megjelenésével született. Jelenleg nem ismert olyan standard eljárás, illetve felhasználóbarát eszköz, amellyel az objektív összehasonlító mérések megvalósíthatók lennének.

A mérések pontatlansága abból a technikai problémából fakad, hogy ugyanazon készülékkel készült felvételek esetében sem garantált, még akár két, közvet- len egymás után készített felvétel esetében sem az, hogy a metszetek ugyanabban a síkban metszik a koponyát, hiszen a páciens pozicionálásában ezt a legkisebb módosítás meghiúsítja.

Az összehasonlítást tovább nehezíti, ha kettő vagy több különböző készülék, esetleg különböző gyártók készülékével készített felvételeket szeretnénk egymással pontosan, objektív, kvantitatív mérésre alkalmas módon összehasonlítani.

Erre a problémára fejlesztettünk ki egy megoldást, amelyben egy radiológiai szoftver segítségével, az ugyanazon páciensről, eltérő időpontban készített CBCTfelvételeket tudjuk egymáshoz szinkronizálni, illetve illeszteni. A képek egymáshoz való illesztése alatt azt értjük, amikor a képen megjelenített anatómiai képletek a teljes vizsgált térfogatban a lehető legpontosabban fedik egymást, kongruensek egymással.

A két különböző CT-felvétel összehasonlításán alapuló mérési módszerek többféleképpen próbálják megoldani a feladatot. A legelterjedtebbek és legpontosabbak a szegmentációs technikával végzett volumen összehasonlításos CT analizáló eljárások. Ezek esetében a pontosság ellenőrzésére a Dice Similarity Indexet (DSI) használják [14]. A vizsgálat lehetséges voxel alapú összehasonlító módszerekkel is, melyeket elsősorban fogszabályozó kezelések esetében használnak, de alkalmazásuk csontpótlás vizsgálatára nehézkes (pl. Dolphin Imaging ${ }^{\mathrm{TM}}$, Patterson Companies Inc., USA) [1]. Az irodalomban leírt, az állcsontokon végzett csontpótló mútétek vizsgálatára alkalmas CT-vizsgálaton alapuló esetekben 3D tervezőprogramokkal (AutoCAD, szabad forrású tervezőprogram) azonos régiókban kijelölt volumenekkel hasonlítottak össze térfogatokat [23], de ezen esetekben a kijelölés módja nem biztosítja egyértelműen a pontos összehasonlítást.

További lehetséges megoldások az egyes felvételeken acélgolyóval történő pozíció-jelölés [5], vagy a CT-felvételek keresztmetszeti képén előre kijelölt regiókban, több magasságban történő csontszélességmérés [16].

Esetünkben a fent leírt technikákkal szemben egyszerúbb, könnyebben használható, pontos, objektív öszszehasonlításra alkalmas módszert fejlesztettünk ki. Az eljárással két különböző időpontban készült CBCTfelvételen az anatómiai pontok alapján kijelölt azonos szeletek azonos felszínei közötti esetleges méretkülönbséget lehet mérni. Ha pontos a kijelölés, a két felvételen nincs méretbeli különbség, a két felszín pontosan egymásra vetül. Amennyiben pontatlan a kijelölés, a két felszín nem fedi pontosan egymást, és a különbség mm-ben mérhető. Csontpótlás esetén a pótolt csontterület méretbeli változását a fenti módszerrel könnyen ki lehet értékelni. llyenkor, a két CBCT-felvétel pontos illesztése esetén a méretbeli eltérés a csontpótolt terület méretváltozását (csontnyereség vagy -veszteség) mutatja.

A legnagyobb pontosságot biztosító, szegmentálással történő volumen-összehasonlításhoz képest egy- 


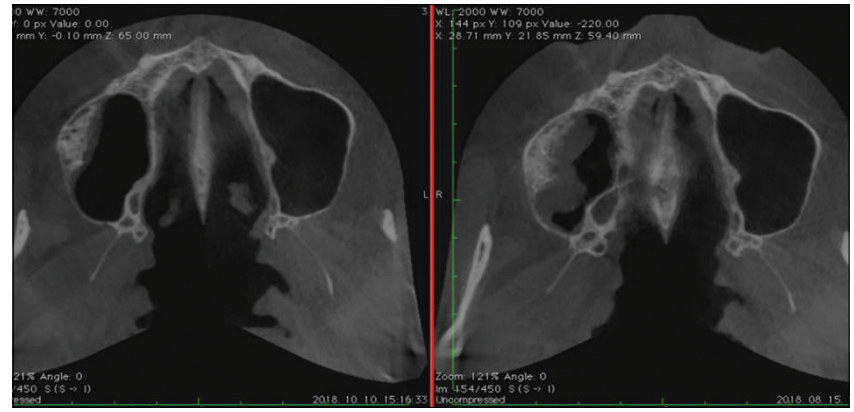

1. ábra

szerübbnek túnik, és kevesebb hibalehetőséget tartalmaz az általunk kidolgozott eljárás.

\section{Célkitúzések}

Célunk a nyílt forráskódú Horos ${ }^{T M}$ orvosi képfeldolgozó program segítségével olyan CBCT-felvételek értékelésén alapuló, összehasonlító analízisére alkalmas módszer létrehozása, ellenőrzése és módszertani ajánlás készítése volt, mely alkalmas a csontpótló mútétek sikerességének objektív mérésére.

További terv: összehasonlítani a szegmentációval történő volumen-összhasonlítást a pontok kijelölésével történő volumen-összahasonlítással.

\section{Vizsgálati anyag és módszer}

Célunk a csontpótló mútétek összehasonlító CBCT analízisére alkalmas módszer létrehozása és ellenőrzése volt, anatómiai pontok meghatározásával, illetve egy ajánlás készítése a mérések pontosságának javítására nyílt forráskódú Horos ${ }^{T M}$ szoftver (GNU Lesser General Public License) segítségével [20]. A Horos ${ }^{T M}$ az Osirix ${ }^{T M}$ zárt forráskódú DICOM (Digital Imaging and Communications in Medicine) képfeldolgozó szoftveren és más nyitott forráskódú programokon alapul.

A kidolgozott módszer lényege, hogy a $\operatorname{Horos}^{T M}$ program segítségével ugyanazon beteg két különböző időpontban készített CBCT felvétele egymásra vetíthető. Ha az egymásra vetített képek illesztési pontossága megfelelő, akkor az illesztés során észlelt eltérés a kijelölt területek méretkülönbségét jelzi [9].

A képsorozatok illesztése ugyanazon páciensről két, eltérő alkalommal készült szkennelt volumenen belül, három tetszőleges pont megjelölésével történt. Ezen pontok segítségével képes a program a metszeteket egymáshoz illeszteni. Minél pontosabban lehet bejelölni a pont-párokat a két összehasonlítandó felvételen, annál pontosabb az illesztés. Az illesztési pontok kiválasztása megvalósulhat ismert anatómiai pontok kijelölésével (pl. lingula mandibulae, foramen mentale, spina nasalis anterior et posterior), illetve egyedi radiológiai jellegzetességeket mutató, mindkét képsorozaton beazonosítható, tetszőleges anatómiai pontok meghatározásával. A legjobb esetben olyan mintázatok azonosítása történik, amelyek csak egy metszeten találhatók meg, tehát a $Z$ koordinátában is igen pontosan behatárolhatók. (1-2. ábra)

A képek illesztése során az egyik volumen a másikkal kongruenssé válik, egy rotációs és/vagy transzlációs korrekció következtében, így a megfelelő metszetek teljes síkjukban ugyanazokat a képleteket, ugyanabban a magasságban metszik. A mérések ezeken a szinkronizált metszeteken valósulnak meg. A két szinkronizált sorozat képpárjainak megfelelő pixelek szürkeértékeit a program kivonja egymásból. Az eredményt a program kép formájában megjelenítve mutatja. Ha ugyanazon képletek két felvételen rögzített kontúrja tökéletesen egymásra vetül, akkor a kivonás eredménye 0 , amit

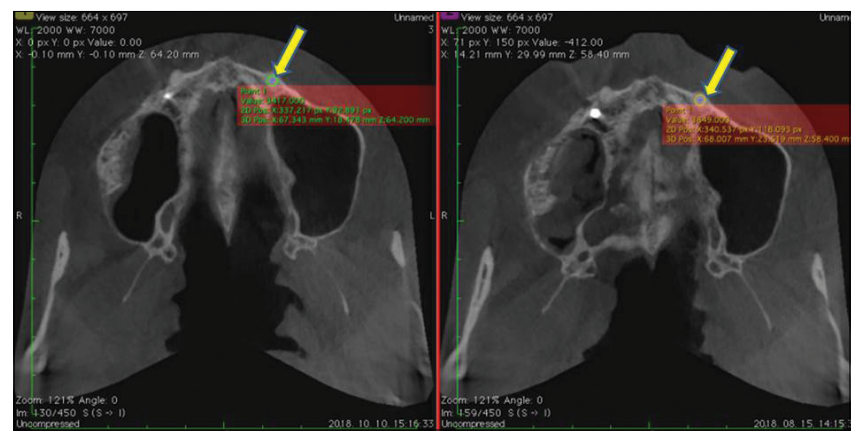

2.a ábra

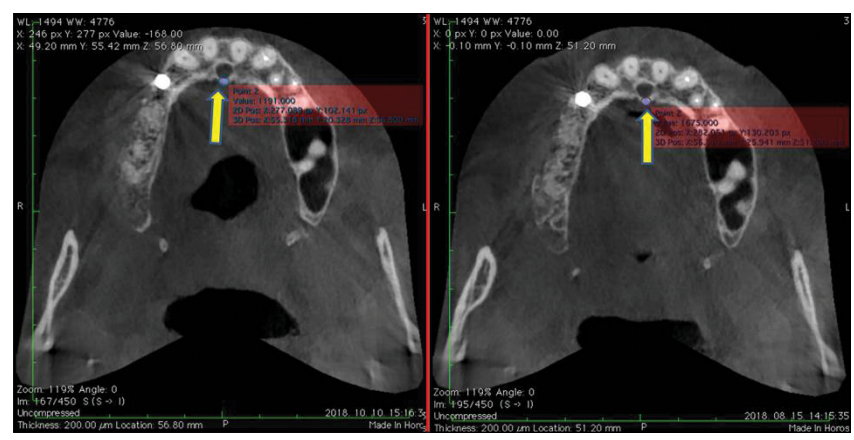

2.b ábra

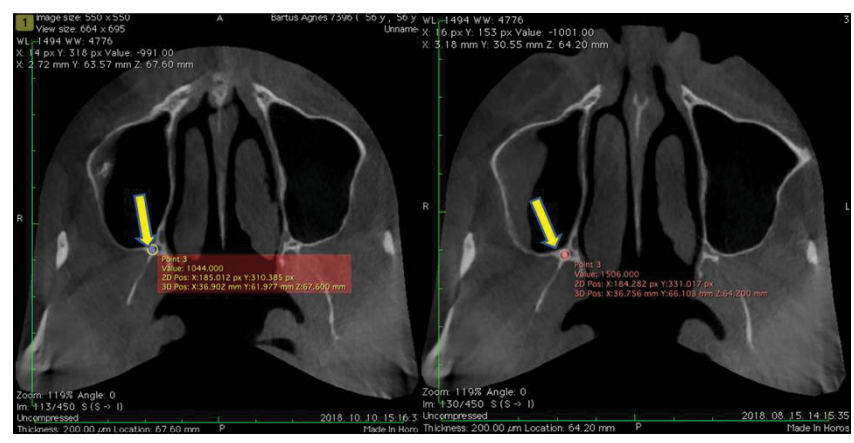

2.c ábra 
a program szürkeként fog megjeleníteni. Ha a múvelet során egy transzlációs és/vagy rotációs illesztési hiba történt, ez a képen egy markáns kontúr-kettőzetet fog eredményezni. A kontúr-kettőzet egyik tagja világos, a másik sötét értékben jelenik meg. (3. ábra)

Ez egy módosított alkalmazása a komplementer színekkel már leírt, hasonló módszernek [20].

A két kontúr közötti távolság az illesztési hiba, ami $\mathrm{mm}$-ben mérhető. Az illesztési hiba mértéke a két különböző időpontban készült felvétel egymásra vetítésének pontosságától függ. Ha az illesztési hiba megfelelően alacsony (a mérendő értékeknél nagyságrendekkel kisebb), a módszer jól alkalmazható objektív összehasonlító mérésekre. (4. ábra) Az illesztési hiba mértékét a megfelelő illesztési pontok megtalálása határozza meg.

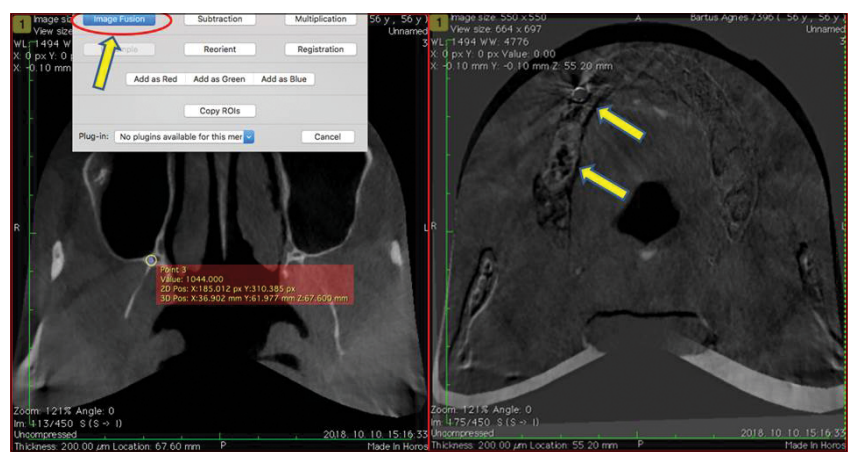

3. ábra

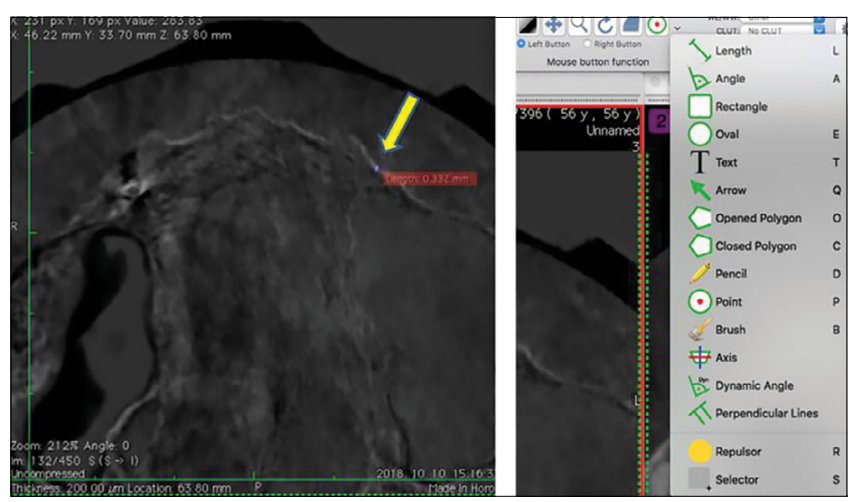

4. ábra
Vizsgálatunk során 6 páciens 2 különböző időpontban készült CBCT-felvételeit hasonlítottuk össze a Horos ${ }^{T M}$ (Horos Project) orvosi képfeldolgozó ingyenes és nyílt forráskódú orvosi képmegjelenítő programmal, amely az Osirix orvosi képfeldolgozó program kódján alapul [19].

A felvételek VATECH CBCT (South Korea) készülékkel történtek a következő beállítások mellett: méret (FOV): $12 \mathrm{~cm} \times 9 \mathrm{~cm}$, szkennelési idő: $17 \mathrm{sec}$, voxel méret: 0,3 mm; hozzávetőleges dózis $=40 \mu S v, 5-7$ panoráma felvételnek megfelelő dózis.

\section{Vizsgálati csoportok}

1) csoport: hat páciens esetében 2 különböző időpontban készített felvételen 3 standard anatómiai pont kijelölése után (spina nasalis anterior, spina nasalis posterior, processus pterygoideus lateralis szárnya), 2) csoport: ugyanazon hat páciens esetében, 3 egyedileg kiválasztott radiológia pont kijelölése alapján történt az egymásra vetítése egy adott páciens két CBCT-felvételének.

\section{Mérések}

Az illesztés során történhet minimális hiba, amely kettős kontúrként jelenik meg a kapott képen. A vizsgálat során ezt a hibát mértük 4 vizsgáló személy bevonásával, csoportonként 3 méréssel. Az egyes csoportok illesztési hiba mértékének (különbségének) értékelése Mann-Whitney U teszttel történt, ahol a standard deviancia kisebb vagy egyenlő volt 0,05-tel.

\section{Eredmények}

A vizsgálati eredmények azt mutatták, hogy minden egyes csoportnál szignifikánsan pontosabb mérési átlagokat kaptunk az egyedi anatómia pontok alapján végzett mérések során, mint a standard pontok alapján végzetteknél. (1. táblázat, 5. ábra)

Az eredmények mind intra- és interobszerver mérések összehasonlítása esetén hasonló eltérést mutattak. (6. ábra)

\begin{tabular}{|l|l|c|c|c|c|}
\hline Mérés módja & & Mérö 1. átlaga & Mérő 2. átlaga & Mérö 3. átlaga & Mérő 4. átlaga \\
\hline Anatómiai pont alapján mért & Mean & 0,46239 & 0,49967 & 0,64706 & 0,60700 \\
\hline & $\mathrm{N}$ & 6 & 6 & 6 & 6 \\
\hline & $\mathrm{SD}$ & 0,103378 & 0,100992 & 0,55575 & 0,069837 \\
\hline Random pont alapján mért & Mean & 0,28311 & 0,31856 & 0,29100 & 0,28144 \\
\hline & $\mathrm{N}$ & 6 & 6 & 6 & 6 \\
\hline & $\mathrm{SD}$ & 0,030116 & 0,040495 & 0,038823 & 0,033452 \\
\hline Összesen & Mean & 0,37275 & 0,40911 & 0,46903 & 0,44422 \\
\hline & $\mathrm{N}$ & 12 & 12 & 12 & 12 \\
\hline & $\mathrm{SD}$ & 0,118472 & 0,119697 & 0,191479 & 0,177851 \\
\hline
\end{tabular}




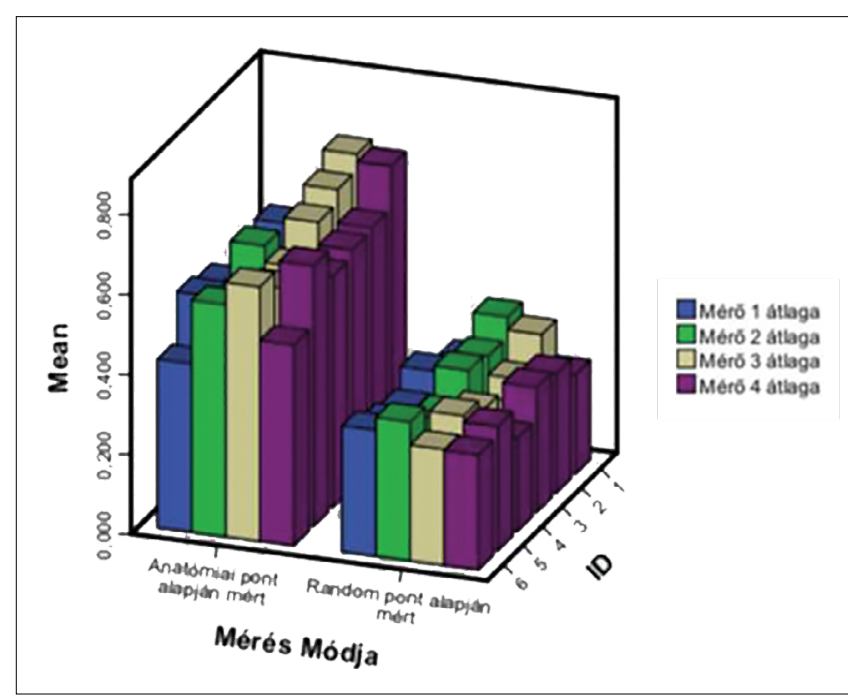

5. ábra

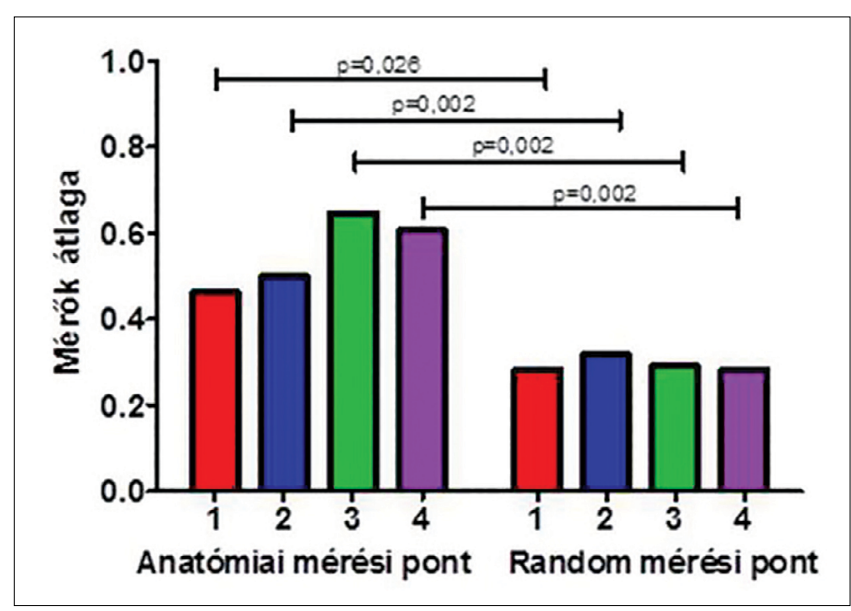

6. ábra

\section{Megbeszélés}

A vizsgálatok során a felvételeken az általánosan használt kefalometriai pontok helyett jól elkülöníthető standard anatómiai pontok vagy egyedi radiológiai pontok alapján történtek a mérések. Erre azért volt szükség, mert az elővizsgálatok során a kefalomatriai pontok kijelölésével végzett mérések szignifikánsan nagyobb szórást mutattak a cikkben szereplő eredményekhez képest. A kefalometriai pontok alapján történt illesztés pontossága rosszabb volt minden esetben (adatok nem kerültek bemutatásra).

Az eredmények azt mutatják, hogy a mérési hiba szignifikánsan magasabb a standard anatómiai méröpontokat használó módszer esetében, mint az egyéni radiológiai jellegzetességeket használó módszernél, mind az intra- és interperszonális mérések esetében. Az eltérés mindkét mérési módszer esetén tizedmilliméteres nagyságrendbe esik, ami azt mutatja, hogy a módszer alkalmas csontpótló műtéti eljárások esetén a nyert csontvolumen objektív mérésére, mivel a mérési hiba nagyságrendekkel kisebb a csontpótlások esetén szükséges csontméret-nyereség mértékénél (általában 2-20 mm), és a két különböző időpontban készített felvételen ezzel a módszerrel pontosan kijelölhető ugyanaz az anatómiai terület.

Az eredmények megerősítést nyújtanak abban, hogy a módszer alkalmas objektív összehasonlító CBCT elemzésre, használata egyszerúbb és gyorsabb a szegmentáláson alapuló eljárásoknál. A még pontosabb mérés elérése érdekében - ha lehetséges - érdemes dentális képleteket kijelölni referenciapontként, olyan módon, hogy a pontok által kijelölt háromszög területe minél nagyobb legyen.

Az intra- és interperszonális mérések közötti minimális eltérés azt igazolja, hogy a módszer alkalmas ugyanazon személy két eltérő időpontban végzett CBCTfelvételének pontos összehasonlító vizsgálatára.

A leírt módszer a képek hárompontos illesztésén alapszik. A felhasznált program a $\operatorname{Horos}^{T M}$ nyílt forráskódú radiológiai számítógépes software, amely lehetőséget nyújt két képsorozat illesztésére. Az illesztés mindkét képsorozaton ugyanazon anatómiai referenciapontok bejelölésével kezdődik. A két képsorozat regisztrálása (szinkronizálása) során ezen pontok helyzete alapján a szoftver átrendezi a metszeteket (az egyik szkennelt volument újrametszi, a másik volumen axiális metszeteivel párhuzamos síkokban).

Az általunk kidolgozott módszer újdonságát az ismert software új aspektusból történő felhasználása jelenti, melynek alkalmazhatóságát és pontosságát vizsgálatainkkal ellenőriztük.

Az illesztés pontosságának meghatározására kidolgoztunk egy egyedi megoldást.

A két szinkronizált sorozat képpárjainak megfelelő pixelek szürkeértékét kivonjuk egymásból. Az eredményt szintén egy kép formájában jelenítjük meg. Ha ugyanazon képleteknek a két felvételen rögzített kontúrja tökéletesen egymásra vetül, akkor a kivonás eredménye 0 , amit a program szürkeként fog megjeleníteni. Ha a múvelet során egy transzlációs és/vagy rotációs illesztési hiba történt, ez a képen egy markáns kontúrkettőzetet fog eredményezni. A kontúr-kettőzet egyik tagja világos, a másik sötét értékben jelenik meg, hiszen az egyik érték pozitív, a másik negatív tartományba kerül a kivonás során. A két kontúr közötti távolság az illesztési hiba mértékétől függ, és az említett software-ben mm-ben mérhető.

Az illesztési pontosságot a térben több pont kijelölésén alapuló szegmentációs eljárással elméletileg pontosítani lehet, azonban ez az eljárás időigényesebb, bonyolultabb és a több pont megfelelö kijelölése is rejthet magában hibaforrást, ezért összehasonlító mérések végzésére a cikkben leírt eljárás egyszerübb, könynyebben kivitelezhető.

A leírt módszer használhatóságát alátámasztja pontossága, egyszerüsége és az a tény, hogy jelentős anyagi befektetés nélkül is elérhető. 


\section{Irodalom}

1. Bazina M, Cevidanes L, Ruellas A, Valiathan $M$, Quereshy $F$, SYED A, et al: Precision and reliability of Dolphin 3-dimensional voxel-based superimposition. Am J Orthod Dentofacial Orthop 2018 Apr; 153 (4): 599-606. https://doi.org/10.1016/j.ajodo.2017.07.025

2. Bressan E, Ferrarese N, Pramstraller M, Lops D, Farina R, TOMASI C: Ridge Dimensions of the Edentulous Mandible in Posterior Sextants: An Observational Study on Cone Beam Computed Tomography Radiographs. Implant Dent 2017 Feb; 26 (1): 66-72. PMID: 27824716 https://doi.org/10.1097/ID.0000000000000489

3. Cortes AR, Cortes DN, Arita ES: Cone beam computed tomographic evaluation of a maxillary alveolar ridge reconstruction with iliac crest graft and implants. J Craniofac Surg 2012 Jan; 23 (1): e12-4. https://doi.org/10.1097/SCS.0b013e3182420789

4. Wismeijer D, Joda T, Flügge T, Fokas G, Tahmaseb A, Bechelli D et al: Group 5 ITI Consensus Report: Digital Technologies. Clin Oral Implants Res 2018 Oct; 29 Suppl 16: 436-442. https://doi.org/10.1111/clr.13309

5. Diez GF, Fontão FN, Bassi AP, Gama JC, Claudino M: Tomographic follow-up of bone regeneration after bone block harvesting from the mandibular ramus. Int J Oral Maxillofac Surg 2014 Mar; 43 (3): 335-340. Epub 2013 Sep 23. PMID: 24070771 https://doi.org/10.1016/j.ijom.2013.08.010

6. Dúcz A, Huszár T, NÉmetH Z, Bogdán S: Comparison of autologous bone graft remodeling from different donor sites in the jaws using cone beam computed tomography. Fogorv Szle 2012 Sep; 105 (3): 91-98. Hungarian. PMID: 23240490

7. Gander T, Bredell M, Eliades T, Rücker M, Essig HJ: Splintless orthognathic surgery: a novel technique using patient-specific implants (PSI). Craniomaxillofac Surg 2015 Apr; 43 (3): 319-322. Epub 2014 Dec 20. PMID: 25600026 https://doi.org/10.1016/j.jcms.2014.12.003

8. Hvid CA, Elstrom UV, Jensen K, Alber M, Grau C: Accuracy of software-assisted contour propagation from planning $C T$ to cone beam CT in head and neck radiotherapy. Acta Oncol 2016 Nov; 55 (11): 1324-1330. Epub 2016 Aug 24. PMID: 27556786 https://doi.org/10.1080/0284186X.2016.1185149

9. Karlo CA., Steurer-Dober I, Leonardi M, et al: MR/CT image fusion of the spine after spondylodesis: a feasibility study. Eur Spine J 19, 1771-1775. (2010) https://doi.org/10.1007/s00586-010-1430-x

10. Klijn RJ, van den Beucken JJ, Bronkhorst EM, Berge SJ, Meijer GJ, JANSEN JA: Predictive value of ridge dimensionson autologous bone graft resorption in staged maxillary sinus augmentation surgery using Cone-Beam CT. Clin Oral Implants Res 2012 Apr; 23 (4): 409-415. Epub 2011 Oct 20. PMID: 22092724 https://doi.org/10.1111/j.1600-0501.2011.02342.x

11. Koppány F, Joób-Fancsaly A, Szabó G: Possible methods for evaluating bone density in the maxillofacial region. Fogorv Szle 2007 Apr; 100 (2): 77-81. Review. Hungarian. PMID: 17546899

12. Magat G, OzCAN SEner S: Evaluation of trabecular pattern of mandible using fractal dimension, bone area fraction, and gray scale value: comparison of cone-beam computed tomography and panoramic radiography. Oral Radiol 2019 Jan; 35 (1): 35-42. Epub 2018 Jan 17. PMID: 30484179 https://doi.org/10.1007/s11282-018-0316-1

13. Naitoh M, Aimiya H, Hirukawa A, AriJ E: Morphometric analysis of mandibular trabecular using cone beam computed tomography: an in vitro study. Int J Oral Maxillofac Implants 2010; 25: 1093-1098.

14. Paumels R, Jacobs R, Bosmans h, Pittayapat P, Kosalagood P, SiLKosessaK $O$, et al: Automated implant segmentation in cone-beam CT using edge detection and particle counting. Int J Comput Assist Radiol Surg 2014 Jul; 9 (4): 733-743. PMID: 24078371 https://doi.org/10.1007/s11548-013-0946-Z

15. Pramstraller M, Farina R, Franceschetti G, Pramstraller $C$, TROMBELLI L: Ridge dimensions of the edentulous posterior maxilla: a retrospective analysis of a cohort of 127 patients using computerized tomography data. Clin Oral Implants Res 2011 Jan; 22 (1): 54-61. Epub 2010 Sep 10. Erratum in: Clin Oral Implants Res 2011 Feb; 22 (2): 235. PMID: 20831759 https://doi.org/10.1111/j.1600-0501.2010.01984.x

16. Pramstraller M, Schincaglia GP, Vecchiatini R, Farina $R$, TrombelLI L: Alveolar ridge dimensions in mandibular posterior regions: a retrospective comparative study of dentate and edentulous sites using computerized tomography data. Surg Radiol Anat 2018 Dec; 40 (12): 1419-1428.

Epub 2018 Aug 23. PMID: 30167819 https://doi.org/10.1007/s00276-018-2095-0

17. Recker RR, Kimmel DB, Dempster D, Weinstein RS, Wronski TJ, BuRR DB: Issues in modern bone histomorphometry.

Bone 2011 Nov; 49 (5): 955-964. Published online 2011 Jul 23. PMCID: PMC3274956 https://doi.org/10.1016/j.bone.2011.07.017

18. Ritter L, Elger Mc, Rothamel D, Fienitz T, Zinser M, Schwarz F, et al: Accuracy of peri-implant bone evaluation using cone beam CT, digital intra-oral radiographs and histology.

Dentomaxillofac Radiol 2014; 43 (6): 20130088. Epub 2014 May 2. PMID: 24786136 https://doi.org/10.1259/dmfr.20130088

19. Rosset A, Spadola L, Ratib O: OsiriX: An Open-Source Software for Navigating in Multidimensional DICOM Images,

O. J Digit Imaging (2004) 17: 205. https://doi.org/10.1007/s10278-004-1014-6

20. http://hdl.handle.net/10380/1458 (2020.05.05.)

21. Suphanantachat $S$, Tantikul K, Tamsailom $S$, Kosalagood $P$, NisAPAKULtorn K, TAVEDHIKUL K: Comparison of clinical values between cone beam computed tomography and conventional intraoral radiography in periodontal and infrabony defect assessment. Dentomaxillofac Radiol 2017 Aug; 46 (6): 20160461. Epub 2017 Mar 23. PMID: 28267927 https://doi.org/10.1259/dmfr.20160461

22. Verdugo F, Simonian K, d'Addona A, Pontón J, Nowzari H: Human bone repair after mandibular symphysis block harvesting: a clinical and tomographic study. J Periodontol 2010 May; 81 (5): 702-709. PMID: 20429649 https://doi.org/10.1902/jop.2010.090612

23. Verdugo F, Simonian K, Raffaelli L, d’Addona A: Computer-aided design evaluation of harvestable mandibular bone volume: a clinical and tomographic human study. Clin Implant Dent Relat Res 2014 Jun; 16 (3): 348-355. Epub 2012 Nov 15. PMID: 23157651 https://doi.org/10.1111/cid.12011 


\section{Definition and standardization of method for comparative Cone Beam Computed Tomography (CBCT) examination of maxillofacial bone surgery}

Exact evaluation of the effectiveness of bone replacement surgery in the maxillofacial region has not been established yet. This is due to the difficulty of comparing images performed at different times. There are softwares suitable for comparative testing, but their application is difficult. A standardized comparison procedure for the maxillofacial region has not been developed yet.

Objective: 1) To develop and test a method for comparative CBCT analysis of bone replacement surgery in the maxillofacial region. 2) Preparation of a methodological recommendation.

Material and Method: CBCT images of 6 patients performed at two different times were compared with Horos $^{T M}$ medical imaging program based on the detection of misalignment. The study was performed by 4 independent investigators. Study groups: 1) Measurements based on standard anatomical points, 2) Measurements based on individual radiological points.

Statistics: 3 measurements in every group, Mann-Whitney $U$ test, $(S D p \leq 0,05)$

Results: The rate of misalignment was significantly lower in case of every measurement based on individual radiolog points than in case of measurements based on anatomical points ( $1^{\text {st }}$ investigator: $0,463 \pm 0,103$ vs. $0,283 \pm 0,030$; $2^{\text {nd }}$ investigator: $0,499 \pm 0,100$ vs. $0,318 \pm 0,040 ; 3^{\text {rd }}$ investigator: $0,647 \pm 0,555$ vs. $0,291 \pm 0,388 ; 4^{\text {th }}$ investigator: 0,607 $\pm 0,069$ vs. $0,281 \pm 0,033$ )

Conclusions: With the Horos ${ }^{T M}$ imaging software, it is possible to perform an objective comparative study of CBCT images preformed at different time of the same person using the "fitting error measurement" method. The most accurate measurements are achieved by the triangular designation of individual radiologoc points.

Keywords: $\mathrm{CBCT}$, comparative $\mathrm{CBCT}$ analysis, bone replacement, maxillofacial region, Horos $^{T M}$ 